\title{
Development of a virtual simulation game on basic life support
}

\author{
Desenvolvimento de um jogo virtual simulado em suporte básico de vida \\ Desarrollo de un juego virtual simulado en soporte básico de vida
}

Isabel Karolyne Fernandes Costa ${ }^{1}$, Manuela Pinto Tibúrcio ${ }^{1}$, Isabelle Katherinne Fernandes Costa ${ }^{1}$, Rodrigo Assis Neves Dantas ${ }^{1}$, Raphael Nepomuceno Galvão ${ }^{1}$, Gilson de Vasconcelos Torres ${ }^{1}$

How to cite this article:

Costa IKF, Tibúrcio MP, Costa IKF, Dantas RAN, Galvão RN, Torres GV. Development of a virtual simulation game on basic life support. Rev Esc Enferm USP. 2018;52:e03382. DOI: http://dx.doi.org/10.1590/S1980-220X2017047903382

1 Universidade Federal do Rio Grande do Norte, Departamento de Enfermagem, Natal, RN, Brazil.

\section{ABSTRACT}

Objective: To validate the content of a virtual learning object in the format of a Role Playing Game - educational simulation game about basic life support, aimed at academics and health professionals. Method: Methodological, construction and validation study with qualitative data approach on the content of a virtual learning object, conducted between August and September 2016. Results: The game was developed in 13 screens, of which nine presented contents of basic life support, and the others presented general guidelines for progress in the game. The five suggestions of the experts were accepted by the researchers, and were mostly related to organization, clarity and vocabulary. No item was considered inappropriate by the judges, and the game had a mean content validity index of 0.96 and a Kappa value of 0.92 . In the Likert scale evaluation, the game was considered in all analyzes as an excellent content for a virtual learning object. Conclusion: This learning technology is expected to support teaching of basic life support techniques for academics and health professionals, and to stimulate the development of similar teaching strategies in other scenarios, in order to bring advancements to the design of health training processes.

\section{DESCRIPTORS}

Cardiopulmonary Resuscitation; Educational Technology; Education, Distance; Simulation; Validation Studies. 


\section{INTRODUCTION}

For a successful teaching of Basic Life Support (BLS), it is necessary to create strategies to stimulate the professionals to take an active part in their own learning ${ }^{(1-5)}$.

Thus, the Guidelines for the Organization of Continuing Healthcare Education propose strategies based on active teaching methodologies in order to change the education of health professionals and foster meaningful learning ${ }^{(6)}$.

The development and validation of a virtual learning object (VLO) is directly related to understanding cyberspace and recognizing the need for tools that must be incorporated into education as a response to a need of the teaching-learning process, since only traditional teaching has not been enough ${ }^{(7)}$.

Within the game world, there is the Role Playing Game (RPG), defined as a cooperative activity in which there is the incorporation of a fictional character and a fictional reality. The combination of action and invention offered by the game can be directed towards improving knowledge and clinical skills ${ }^{(8-11)}$.

Given the importance of teaching BLS and the need to create strategies to promote learning on this topic among academics and health professionals, the following research question is proposed: how to structure the content of a VLO in the format of an educational simulation game about BLS?

The purpose of this study was to validate the content of a virtual learning object in the format of a Role Playing Game - educational simulation game on basic life support, aimed at academics and health professionals.

\section{METHOD}

This is a methodological, construction and validation study, aimed at structuring and analyzing the content validity of a Virtual Learning Object in the format of a Role Playing Game, designed for the evaluation of BLS in academics and health professionals ${ }^{(10)}$.

The content validation process was based on the theoretical framework of the Pasquali model ${ }^{(12)}$ and occurred through the identification of the content that composed the VLO and content validation with area experts and validation analysis.

The instrument was constructed in August 2016, by an intentionally selected team composed of three content specialists. The inclusion criterion was having 5 years of experience in the area of basic life support, with research and studies published in the area.

The construction of the VLO was based on literature review and on the American Heart Association's (AHA) most up-to-date BLS international protocols, published in 2015. In addition, it had the pedagogical support of Ausubel's theory of Meaningful Learning. These conceptions were originally thought for a BLS distance learning course, but they can also support face-to-face BLS courses, making the formative evaluation process more dynamic.

The validation stage occurred in September 2016. The judges were chosen considering Pasquali's (2010) ${ }^{(12)}$ orientation on the minimum number of judges necessary for content evaluation and through the non-probabilistic technique, selecting the participants in a network for their accessibility. A total of six specialists in the areas of Nursing and Medicine, who were part of the Mobile Emergency Care Service of the state of Rio Grande do Norte (SAMU 192 RN), were selected.

As a criterion for the selection of specialists, The Fehring's 1994 scoring system ${ }^{(13)}$ was adapted and used as criterion for the selection of specialists, considering the minimum of five points.

Therefore, inclusion criteria were: having a master's degree in nursing or health sciences (2 points); being an instructor/professor of basic life support in an University or in Continuing Education Centers (2 points); being a researcher in the area of teaching/learning methods or basic life support (1 point); having an article published in the area of teaching/learning methods or BLS in a recognized journal ( 2 points); having a $\mathrm{PhD}$ with thesis in the area of teaching methodologies or BLS (2 points); be working for at least 5 years in a hospital or pre-hospital emergency service (3 points); having a certificate of specialization or residence in the emergency/intensive care/pre-hospital area ( 2 points). The exclusion criterion was specialists who were away from professional practice/education for more than 2 years. However, there were no exclusions.

The content validation tool had variables related to the personal and professional characteristics of the experts, and the judge evaluated 13 questions related to the content of the VLO, namely: 1 - evaluation of overall content, 2 - organization, 3 - presentation, 4 - utility/pertinence, 5 - consistency, 6 - clarity, 7 - objectivity, 8 - reliability, 9 - feasibility, 10 - updated, 11 - vocabulary, 12 - instructional sequence of the items and 13 - learning assessment ${ }^{(12)}$.

Each item of the VLO could be classified as adequate, adequate with changes or inadequate. When the specialists classified the item as adequate with changes or inadequate, a space was provided for them to justify the reason(s) and suggest improvements. The judges were then asked to rate the VLO on a Likert scale of 1 to 10 , with 1 being the lowest possible quality and 10 being the highest possible quality.

After the data collection phase, the information obtained through the form were organized in a spreadsheet on Microsoft Office Excel for Windows. Subsequently, the data were inserted into a database on SPSS software version 20.0 for Windows, in order to obtain the final results for further discussions based on relevant literature.

The data were analyzed using the Content Validity Index (CVI). Indices higher than 0.80 were considered acceptable for the general evaluation of the $\mathrm{VLO}^{(10,14)}$.

The analysis also included the Kappa Index (K) with the objective of measuring the level of agreement and consistency of the experts in relation to the content. The value $\geq 0.65$ was established as acceptance criterion, being considered a good index ${ }^{(10,14)}$.

Judges could suggest changes in the text even if the item had a good Kappa, in order to improve the quality of the instrument. It is worth noting that there was only one round of expert evaluation due to the excellent level of agreement between them. 
Chart 1 - Brief definition of the items evaluated by the judges - Natal, RN, Brazil - 2017.

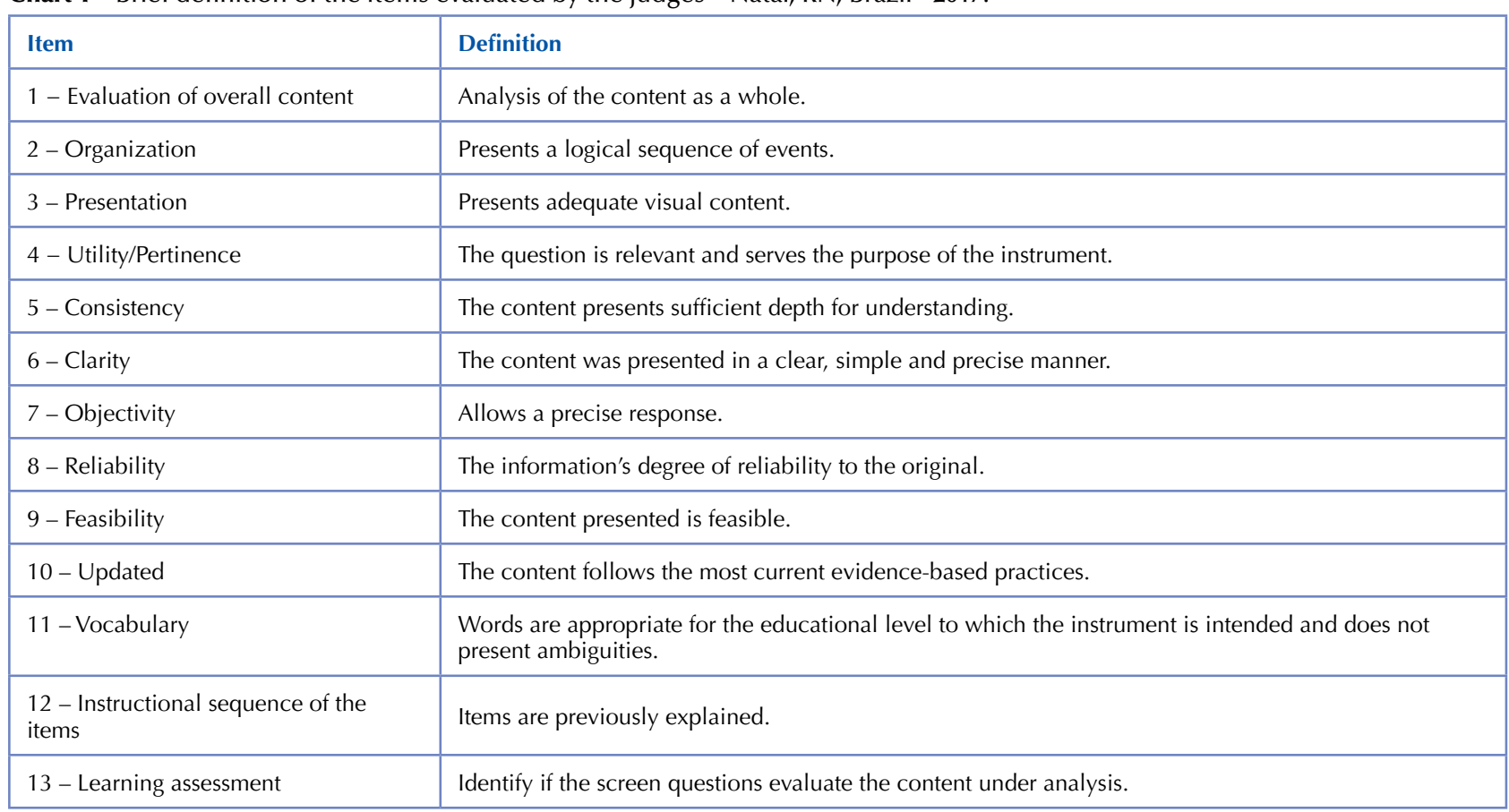

Source: Pasquali (2010)(12)

The study proposal was evaluated and approved by the Research Ethics Committee, through protocol no. 1.709.004, CAAE: 58511516.0.0000.5292, and all participants voluntarily signed the Consent Form (TCLE).

\section{RESULTS}

In the validation process, three (50.0\%) of the six judges who evaluated the instrument were female. The judges had a mean age of $41.3( \pm 6.47)$ years, were mainly nurses (4; 66.7\%) and worked in the Mobile Emergency Care Service or other pre-hospital services $(5 ; 83.3 \%)$. Three $(50 \%)$ had a master's degrees as their highest degree. Regarding professional experience, the judges presented a mean of 14.5 $( \pm 6.35)$ years of experience in care, $10.10( \pm 3.43)$ years in the emergency department and $10( \pm 8.07)$ years in teaching.

The problem situation involves a CPR (cardiopulmonary resuscitation) along with a rescuer who has just taken a distance learning BLS course (EaD). In this context, João Pedro is a fictitious character who, while walking alone in the sidewalk of a beach, began to feel a sharp pain in his chest and suddenly collapsed. This scenario is witnessed by another character, the rescuer (the student of the BLS course), who must apply his BLS knowledge to save João Pedro's life.

Each VLO screen shows an animation following the sequence of events since the initial problem situation and proposes a question to the rescuer (student of the course), requesting an action related to BLS protocols.

The elaboration of the script prioritized the gradual complexity of the knowledge acquired in the thematic units of the BLS course, and the texts and animations were organized with meticulous care to facilitate the student's learning. The VLO had 13 screens, of which 9 presented BLS contents, and the others, general orientations for the progress of the game, as it can be seen in Chart 2, which summarizes the screens, the general objective and the components of the simulated game script.

It should be noted that the instructions of the VLO stated that, in order to advance in the game, the student would need to choose correct BLS actions to respond to the questions that appeared along with the animations of the proposed situation. For achieving success in the game, the student would have to complete it with the maximum of three wrong attempts. If the student failed more than three times, the victim's death screen appeared and the VLO encouraged the student to review some concepts and contents in the units of the BLS course before returning for a new attempt. The student who arrived at the final screen of success in the CPR could improve his time and right answers, making new attempts in the VLO.

In the validation process, 13 evaluation requirements adapted from Pasquali were considered and later analyzed through the CVI (Table 1).

The expert suggestions for all screens were assessed for their suitability, and the VLO was modified for content improvement. Chart 3 presents the five suggestions of the judges for the improvement of the screens, which were all considered adequate and were accepted by the researchers. Most of them were related to organization, clarity and vocabulary.

The screens that received no suggestions were not addressed in Chart 3 and were maintained according to the original screens shown in Chart 2.

It should be noted that no item was considered inappropriate by the judges. The VLO presented a mean value of 0.96 in the analysis of the CVI and a Kappa value of 0.92. In the Likert scale, the VLO received a mean score of 9.67. In all analysis, the content was considered excellent for a VLO in BLS in the format of an educational simulation game. 
Chart 2 - Screens of the Virtual Learning Object aimed at supporting BLS teaching for academics and health professionals - Natal, RN, Brazil - 2017.

\begin{tabular}{|c|c|}
\hline Screen/Objectives & Components of the game script \\
\hline $\begin{array}{l}\text { Presentation screen/ } \\
\text { - Presenting the problem } \\
\text { situation }\end{array}$ & $\begin{array}{l}\text { - Simulated scenario: João Pedro is a } 40 \text {-year old nursing technician who was spending his vacation in } \\
\text { Natal/RN. One fine morning, as he was taking a walk on the beach esplanade, he felt a pressure in his chest, } \\
\text { followed by severe pain radiating to his left arm and back. An intense, cold sweating began to afflict Joao } \\
\text { Pedro, who found a nearby bench and sat down. When he realized that his condition was getting worse, he } \\
\text { asked people who were passing by for help. Then he lost consciousness and fainted. }\end{array}$ \\
\hline $\begin{array}{l}\text { Instructions screen/ } \\
\text { - Presenting the objective of the } \\
\text { VLO and the instructions for the } \\
\text { student progress in the game }\end{array}$ & $\begin{array}{l}\text { - Objective of the simulation and orientation regarding the contents necessary to save João Pedro's (the } \\
\text { victim) life; } \\
\text { - Navigation instructions; } \\
\text { - The student will play the role of rescuer in the simulation game. }\end{array}$ \\
\hline $\begin{array}{l}1 \text { st } \text { content screen/ } \\
\text { - Contextualizing the position of } \\
\text { the student (active subject in the } \\
\text { game) in relation to the problem } \\
\text { situation } \\
\text { - Beginning the assistance to } \\
\text { João Pedro }\end{array}$ & $\begin{array}{l}\text { - Stopwatch on; } \\
\text { - Animation shows the rescuer watching the victim collapse; } \\
\text { - Four multiple choice alternatives with actions to be taken with the victim fainting and safe scene; } \\
\text { - Wrong answer generates feedback "wrong choice, please try again"; } \\
\text { - Right answer generates animation showing the rescuer testing responsiveness and with cellphone on } \\
\text { speaker calling the Mobile Emergency Care Service (SAMU 192). }\end{array}$ \\
\hline $\begin{array}{l}2^{\text {nd }} \text { content screen/ } \\
\text { - Evaluating pulse and breath }\end{array}$ & $\begin{array}{l}\text { - Four multiple choice alternatives with options to check pulse; } \\
\text { - Wrong answer generates feedback "wrong choice, please try again"; } \\
\text { - Right answer generates animation: rescuer palpates carotid pulse, simultaneously observes chest and } \\
\text { diagnoses CPR. }\end{array}$ \\
\hline $\begin{array}{l}3^{\text {rd }} \text { content screen/ } \\
\text { - Beginning } 30 \text { chest } \\
\text { compressions } \\
\text { - Identifying the correct location } \\
\text { of compressions in the victim's } \\
\text { chest }\end{array}$ & $\begin{array}{l}\text { - Four multiple choice alternatives with actions to be taken after CRP diagnosis; } \\
\text { - Wrong answer generates feedback "wrong choice, please try again"; } \\
\text { - Right answer generates animation: rescuer opens the shirt and new options regarding the location to } \\
\text { start compressions appear; wrong answer generates the option to try again, right answer generates next } \\
\text { animation. }\end{array}$ \\
\hline $\begin{array}{l}4^{\text {th }} \text { content screen/ } \\
\text { - Identifying the frequency } \\
\text { (rhythm) of chest compressions }\end{array}$ & $\begin{array}{l}\text { - Four multiple choice alternatives with compression frequencies; } \\
\text { - Wrong answer generates feedback "wrong choice, please try again"; } \\
\text { - Right answer generates animation: rescuer performing the compressions at the right frequency. }\end{array}$ \\
\hline $\begin{array}{l}5^{\text {th }} \text { content screen/ }- \\
\text { Identifying the depth of chest } \\
\text { compressions }\end{array}$ & $\begin{array}{l}\text { - Ruler is shown; } \\
\text { - Three options of blocks of centimeters are shown for the rescuers to select the correct option; } \\
\text { - If the rescuer defined the wrong mark, he receives the feedback message: "Ineffective compression. Try } \\
\text { again". If the rescuer chose the correct mark, he receives the feedback message: "Compression was effective. } \\
\text { Perform } 30 \text { chest compressions". }\end{array}$ \\
\hline $\begin{array}{l}6^{\text {th }} \text { content screen/ } \\
- \text { Opening airway }\end{array}$ & $\begin{array}{l}\text { - The rescuer has one hand on the victim's forehead and is asked about where to place the other hand to } \\
\text { open the airway. Four alternatives appear; } \\
\text { - Wrong answer generates feedback "wrong choice, please try again"; } \\
\text { - Right answer generates animation: opening of the airway, through hyperextension of the head and } \\
\text { elevation of the chin. }\end{array}$ \\
\hline $\begin{array}{l}7^{\text {th }} \text { content screen/ } \\
\text { Performing ventilations }\end{array}$ & $\begin{array}{l}\text { - Four multiple choice alternatives with actions related to ventilation; } \\
\text { - Wrong answer generates feedback "wrong choice, please try again"; } \\
\text { - Right answer generates animation: rescuer gets a CPR pocket mask on the backpack and performs two } \\
\text { ventilations lasting } 1 \text { second each. Now the rescuer takes an Automatic External Defibrillator (AED) out of } \\
\text { the backpack. }\end{array}$ \\
\hline $\begin{array}{l}8^{\text {th }} \text { content screen/ } \\
\text { - Operating the AED correctly }\end{array}$ & $\begin{array}{l}\text { - Four multiple choice alternatives with actions related to the position of the AED electrodes; } \\
\text { - Wrong answer generates feedback "wrong choice, please try again"; } \\
\text { - Right answer generates animation: rescuer puts the paddles in the correct position and the sound indicates } \\
\text { that the AED is analyzing the heart rate. Then the screen shows the rescuer following the commands of the } \\
\text { device to defibrillate. }\end{array}$ \\
\hline $\begin{array}{l}9^{\text {th }} \text { content screen/ } \\
\text { - Restarting chest compressions }\end{array}$ & $\begin{array}{l}\text { - Four multiple choice alternatives with actions to be taken after shock; } \\
\text { - Wrong answer generates feedback "wrong choice, please try again"; } \\
\text { - Right answer generates animation: the rescuer performs chest compressions. Curious faces appear, looking } \\
\text { at the work of the rescuer. João Pedro reacts and begins to move. The curious crowd begins to applaud. }\end{array}$ \\
\hline $\begin{array}{l}\text { Success in Cardiopulmonary } \\
\text { Resuscitation (CPR) screen)/ } \\
\text { - Congratulating for the success } \\
\text { on BLS actions }\end{array}$ & $\begin{array}{l}\text { - Message of congratulations on the fact that João Pedro regained spontaneous circulation thanks to the } \\
\text { rescuer (player), and that he will now be transported by the SAMU team to a Hospital for post-resuscitation } \\
\text { care. }\end{array}$ \\
\hline $\begin{array}{l}\text { Death screen/ } \\
\text { - Evidencing that there were } \\
\text { failures in the BLS }\end{array}$ & $\begin{array}{l}\text { - Message saying that João Pedro did not resist due to failures in BLS actions or delay in the onset of chest } \\
\text { compressions. This screen is shown after the rescuer (player) has lost all three chances of saving the victim } \\
\text { due to inappropriate actions. }\end{array}$ \\
\hline
\end{tabular}


Table 1 - Judgment on the VLO (simulated game) in BLS- Natal, RN, Brazil - 2017.

\begin{tabular}{|c|c|c|}
\hline Evaluation requirements & CVI & Kappa \\
\hline Evaluation of overall content & 1.00 & 1.00 \\
\hline Organization & 0.83 & 0.67 \\
\hline Presentation & 1.00 & 1.00 \\
\hline Utility/Pertinence & 1.00 & 1.00 \\
\hline Consistency & 1.00 & 1.00 \\
\hline Clarity & 0.83 & 0.67 \\
\hline Objectivity & 1.00 & 1.00 \\
\hline Reliability & 1.00 & 1.00 \\
\hline Feasibility & 1.00 & 1.00 \\
\hline Updated & 1.00 & 1.00 \\
\hline Instructional sequence of the topics & 1.00 & 1.00 \\
\hline Learning assessment & 1.00 & 1.00 \\
\hline Mean CVI & 0.96 & 0.92 \\
\hline
\end{tabular}

Chart 3 - Judges' suggestions and changes on the content of the screens of the VLO in BLS - Natal, RN, Brazil 2017.

\begin{tabular}{|c|c|c|}
\hline Screen/Objective & Suggestions (n) & Alterations \\
\hline $\begin{array}{l}2^{\text {nd }} \text { content screen - } \\
\text { Evaluating pulse and breath }\end{array}$ & $\begin{array}{l}\text { - Assess time spent to verify } \\
\text { pulse and breath (1) }\end{array}$ & $\begin{array}{l}\text { - Second stopwatch is added; } \\
\text { - Feedback on wrong action added: "you lost more than } 10 \text { seconds checking } \\
\text { the pulse, João Pedro will have sequels"; } \\
\text { - Right answer within } 10 \text { seconds generates animation: resuscitator palpates } \\
\text { carotid pulse, simultaneously observes chest and diagnoses CPR }\end{array}$ \\
\hline $\begin{array}{l}4^{\text {th }} \text { content screen - } \\
\text { Identifying the frequency } \\
\text { (rhythm) of chest } \\
\text { compressions }\end{array}$ & $\begin{array}{l}\text { - Check how the song } \\
\text { "Stayin' Alive" by Bee } \\
\text { Gees could appear to help } \\
\text { memorizing the rhythm of } \\
\text { the compressions }(1)\end{array}$ & $\begin{array}{l}\text { - In the animation that follows the right answer, the script was rearranged, } \\
\text { so that two scenes are shown. On the first scene the rescuer performs the } \\
\text { compressions on the frequency of the song, and on the second scene the } \\
\text { rescuer remembers a moment in the classroom, when he was listening to } \\
\text { "Stayin' Alive" by Bee Gees on his headphones and tapping his foot in the } \\
\text { rhythm of the song. }\end{array}$ \\
\hline $\begin{array}{l}5^{\text {th }} \text { content screen } \\
\text { - Identifying the depth of } \\
\text { chest compressions }\end{array}$ & $\begin{array}{l}\text { - Add the reasons for } \\
\text { the ineffectiveness of the } \\
\text { compressions in the wrong } \\
\text { alternatives (1) }\end{array}$ & $\begin{array}{l}\text { - Addition in the feedback. If the rescuer chooses the mark of } 0 \text { to } 4 \mathrm{~cm} \text { in } \\
\text { the ruler, he receives the message: "Very superficial compression. It cannot be } \\
\text { effective. Try again"; If the rescuer chooses the mark of } 6 \text { to } 7 \mathrm{~cm} \text { in the ruler, he } \\
\text { receives the message: "Very deep compression. You are using excessive force. } \\
\text { Risk of rib fractures. Try again". And if the rescuer chooses the mark of } 5 \text { to } 6 \\
\mathrm{~cm} \text {, he receives the message: "Compression was effective. Perform } 30 \text { chest } \\
\text { compressions". }\end{array}$ \\
\hline $\begin{array}{l}7^{\text {th }} \text { content screen } \\
- \text { Performing ventilations }\end{array}$ & $\begin{array}{l}\text { - It is weird that a rescuer in } \\
\text { the middle of the street has } \\
\text { an AED in the bag (1) }\end{array}$ & $\begin{array}{l}\text { - The script of the animation was restructured. After the correct ventilation, } \\
\text { a SAMU ambulance is seen in the background. The rescuer and the SAMU } \\
\text { professional merge into a single person dressed as a SAMU professional and } \\
\text { carrying an AED. }\end{array}$ \\
\hline $\begin{array}{l}9^{\text {th }} \text { content screen } \\
\text { - Restarting chest } \\
\text { compressions }\end{array}$ & $\begin{array}{l}\text { - Reuse the Bee Gee's song } \\
\text { "Stayin' Alive" (1); } \\
\text { - Grammatical corrections } \\
\text { (1) }\end{array}$ & $\begin{array}{l}\text { - CPR process occurs to the sound of the song "Stayin' Alive" by Bee Gees; } \\
\text { - Textual corrections were made. }\end{array}$ \\
\hline
\end{tabular}

\section{DISCUSSION}

The proposed VLO was based on Ausubel's Theory of Meaningful Learning. In fact, the content was based in a situation that is easily imaginable and already exists in the cognitive structure of the learner (subsumption), because it is part of the daily routine of any human being and especially of a health academic or professional ${ }^{(11,15-17)}$.

A study on the use of a VLO in the form of a simulation game based on meaningful learning, which was conducted in the Ain Shams University in Egypt with nursing students in cardiology practice, revealed statistically significant differences in students' knowledge on post-test scores, as well as positive feedback on the VLO ability to promote independent learning ${ }^{(8)}$.

Simulation games have been used in health teaching as a pedagogical strategy that stimulates the search for knowledge with a focus on interactivity, problem-based teaching and active participation ${ }^{(8,11,18)}$.

The judges made suggestions on the content of the script in order to make it clearer, more concise, comprehensible and improve the presentation of the subject, the implications for the practice of BLS, the fidelity of the theme presented and the possibility of stimulating critical thinking. The specialists 
classified the VLO as pertinent to be used by academics and health professionals and validated this resource to support teaching on this topic.

With this purpose, on the $2^{\text {nd }}$ content screen (evaluate pulse and breath), a judge suggested that the time the student spends to respond to the question on pulse and breath evaluation should be recorded. As the game already had a stopwatch that started on the first screen, the researchers chose to add a second stopwatch when the question was activated. In addition, the following message was added in the wrong behavior feedback: "you lost more than $10 \mathrm{sec}-$ onds checking the pulse, João Pedro will have sequels". In addition, the answer was considered correct only when the student/rescuer was able to mark the alternative that indicated the location of the carotid pulse within 10 seconds.

The new AHA guidelines ${ }^{(2,19)}$ state that health professionals should evaluate breath and pulse simultaneously in less than 10 seconds, with the intention of minimizing delays in compressions and encouraging speed and efficiency in the evaluation and response, instead of a slow, methodical and step-by-step approach. Thus, a study ${ }^{(21)}$ recommends the use of devices to evaluate the time spent checking the pulse of victims with suspected CPR on training activities. However, other studies show that even trained health professionals have difficulty confirming the presence or absence of pulse in the diagnosis of CPR and that, in doubt, one should not waste time and start CPR protocols more quickly ${ }^{(20-21)}$.

The $4^{\text {th }}$ content screen (identifying the rate/rhythm of chest compressions) and the $9^{\text {th }}$ screen (restarting chest compressions) received similar suggestions. The researchers found the suggestion of including the Bee Gee's song "Stayin' Alive" at the time of chest compressions (animation) very pertinent. The use of the song is aimed at contributing to the learning process and keeping the compression rate between 100 and 120 compressions per minute ${ }^{(2,22-23)}$.

Regarding this topic, it is important to note that, in the last 50 years, there has been a progressive increase in the recommended rate of chest compressions during $\mathrm{CPR}^{(23)}$. In 1960 , the recommended rate was 60 compressions/minute; in 2005, it was increased to approximately 100 compressions/ minute; in 2010, to at least 100 compressions/minute; and by 2015 , consensus based on scientific evidence was reached, setting the upper limit as 120 compressions per minute ${ }^{(2,22)}$.

In this context, in an attempt to improve the quality of CPR according to judges' suggestion regarding the Bee Gees' song, researchers at the University of Texas, USA, submitted resident physicians from all graduate courses and third and fourth-year medical students to CPR training. One group did the training listening to a digital recording of "Stayin' Alive" by Bee Gees and the other group did the same training without the song. Before training, the music length was verified using MixMeister BPM Analyzer (103 beats per minute $)^{(23)}$. After at least 5 weeks, participants were reevaluated without listening to the song. The results of this study showed that compression rates did not significantly vary between groups in the two evaluation, being maintained between 100 and 120 compressions/minute; however, the subjects felt that the music effectively improved their ability to provide CPR in accordance with the AHA guidelines and felt more confident about performing BLS in an actual patient ${ }^{(23)}$.

A randomized controlled study on the effects of music on CPR training, conducted in the School of Nursing in Turkey, collected results twice. The first evaluation was conducted one day after CPR training, and the second evaluation was conducted six weeks after the initial training. The first evaluation shows that the participants in the intervention group had a mean rate of $107.33 \pm 7.29$ chest compressions per minute, whereas the rate for the control group was 121.47 \pm 12.91 . The second evaluation shows that the rates of chest compression for the intervention and control groups were $106.24 \pm 8.72$ and $100.71 \pm 9.54$, respectively ${ }^{(24)}$.

These results demonstrate, once again, that the use of songs with beats within the limits established in the CPR guidelines for chest compressions allows the students to remember the ideal rhythm for compression. This approach can be easily integrated into the BLS education, since it does not require additional technology and it is a cheap resource ${ }^{(24)}$.

In the $5^{\text {th }}$ content screen (identifying the depth of chest compressions), a judge suggested that the consequences of ineffectiveness of the compressions should be added in the feedback of the wrong alternatives. In this sense, a study ${ }^{(22)}$ identified that chest compression depth became lower as chest compression rates became faster, especially with rates above 140/minute. Adequate depth of chest compressions is considered a very important determinant of outcome from cardiac arrest; so, loss of depth may be one mechanism accounting for the decreased success of resuscitation. On the other extreme, depths greater than $6 \mathrm{~cm}$ can lead to severe iatrogenies ${ }^{(2)}$.

On this aspect, the researchers searched the literature and realized that VLOs that are based on simulation should enable the student to experience the consequences of wrong decisions through feedback mechanisms programmed to facilitate learning ${ }^{(25)}$. Therefore, adding the consequences of a wrong decision regarding the depth of compression in the feedback was a pertinent and very important consideration for the learning process proposed by the VLO.

The judge's found the animation that appears at the end of the $7^{\text {th }}$ content screen, "Now the rescuer takes an AED out of the backpack" very strange. Regarding this topic, the researcher found that, in Brazil ${ }^{(26)}$, several cities and states already have legislation on the obligatory existence of AEDs in public places and/or in large circulation events, such as in the states of Rio Grande do Sul (Law no. 13.109/08), Paraná (Law no 14.649/05), São Paulo (Law no. 12.736/07), Maranhão (Law no. 8.283/05), Santa Catarina (State Law no. 97/09) and Federal District (Law n. ${ }^{\circ} 3.585 / 05$ ). However, a study ${ }^{(26)}$ shows that this is still a distant reality in the country, and that, even with the difficulties of the Brazilian health system, SAMUs are those that effectively circulate with AEDs at the service of the population.

Faced with the facts, the researchers chose to use the resource of the illusion, imagination and invention, available in the Role Playing Game (RPG), the simulation game 
style proposed in this research ${ }^{(11)}$. Therefore the rescuer in the street, while observing the SAMU ambulance arriving, quickly transformed into the professional of the pre-hospital mobile service, who was carrying an AED and was able to easily operate it in the subsequent screens.

The active participation of the student in the imaginary possibilities in RPG games was highlighted in a study that proposed a simulation game for different scenarios of nurses' performance ${ }^{(11)}$. A similar proposal was observed in a research on a simulation game on advanced life support aimed at nursing students. This study highlighted motivation and involvement as indispensable to learning and to the development of skills ${ }^{(11,27)}$.

As a limitation of this study, the absence of a clinical validation stage with the judges during the course on the virtual platform itself can be highlighted. In addition, the lack of a second round of evaluation on the content changed after the first trial can also be pointed as a limitation.

\section{CONCLUSION}

The VLO, in the format of an educational simulation game, constructed in 13 screens, of which 9 presented BLS contents and the others had general orientations for progress in the game, was a pedagogical strategy approved by specialists in the area. The VLO can, in a ludic and interactive manner, make the student feel closer to the professional practice and favor reflection and thinking. Therefore, the VLO, which was based on current references of the American Heart Association and on Ausubel's theory of Meaningful Learning, may allow students to experience a situation similar to real life.

The five suggestions of the judges, which were mostly related to organization, clarity and vocabulary, were considered pertinent and were accepted by the researchers. It should also be noted that no item was considered inappropriate by the judges, and the VLO presented a mean value of 0.96 in the analysis of the CVI and a Kappa value of 0.92. In the Likert scale, the VLO received a mean score of 9.67. In all analysis, the content was considered excellent for a VLO in BLS in the format of an educational simulation game.

Future studies should conduct other validity tests in order to confirm the instrument's psychometric properties after clinical application. After theoretical validation, the VLO in BLS is expected to support teaching of this subject for academics and health professionals and to stimulate the development of similar teaching strategies in other scenarios, in order to bring advancements to the design of health training processes.

The virtual learning object under study is valid and safe for training in basic life support. The validity test suggested would only evaluate other methodological criteria that were not contemplated in this study.

\section{RESUMO}

Objetivo: Validar o conteúdo de um objeto virtual de aprendizagem no formato de jogo educativo simulado, tipo Role Playing Game, sobre suporte básico de vida para acadêmicos e profissionais de saúde. Método: Estudo metodológico, de construção e validação de conteúdo de um objeto virtual de aprendizagem, com abordagem quantitativa dos dados, realizado entre agosto e setembro de 2016. Resultados: $\mathrm{O}$ jogo foi desenvolvido em 13 telas, nove apresentaram conteúdos de suporte básico de vida, e as demais, orientações gerais para o avançar do jogo. As cinco sugestões dos especialistas foram acatadas pelos pesquisadores, a maioria relacionada aos quesitos organização, clareza e vocabulário. Nenhum item foi considerado inadequado pelos juízes, e o jogo apresentou um valor médio de 0,96 de índice de validade de conteúdo e 0,92 de Kappa. $\mathrm{Na}$ avaliação pela escala de Likert, o jogo foi considerado em todas as análises um excelente conteúdo para um objeto virtual de aprendizagem. Conclusão: Espera-se que esta tecnologia de aprendizagem possa apoiar o ensino das técnicas de suporte básico de vida para acadêmicos e profissionais de saúde, assim como estimular o desenvolvimento de estratégias de ensino como esta em outros cenários, a fim de avançar no delineamento dos processos formativos em saúde.

\section{DESCRITORES}

Reanimação Cardiopulmonar; Tecnologia Educacional; Educação a Distância; Simulação; Estudos de Validação.

\section{RESUMEN}

Objetivo: Validar el contenido de un objeto virtual de aprendizaje en el formato de juego educativo simulado, tipo Role Playing Game, sobre soporte básico de vida para académicos y profesionales sanitarios. Método: Estudio metodológico, de construcción y validación de contenido de un objeto virtual de aprendizaje, con abordaje cuantitativo de los datos, realizado entre agosto y septiembre de 2016. Resultados: El juego fue desarrollado en 13 pantallas, nueve presentaron contenidos de soporte básico de vida, y las demás, orientaciones generales para el avance en el juego. Las cinco sugerencias de los expertos fueron aceptadas por los investigadores, la mayoría relacionada con los requisitos organización, claridad y vocabulario. Ningún ítem fue considerado inadecuado por los jueces, y el juego presentó un valor medio de 0,96 de índice de validad de contenido y 0,92 de kappa. En la evaluación por la escala de Likert, el juego fue considerado en todos los análisis como un excelente contenido para un objeto virtual de aprendizaje. Conclusión: Se espera que esta tecnología de aprendizaje pueda apoyar la enseñanza de las técnicas de soporte básico de vida para académicos y profesionales sanitarios, así como estimular el desarrollo de estrategias de enseñanza como esta en otros entornos, a fin de avanzar en el diseño de los procesos formativos en salud.

\section{DESCRIPTORES}

Reanimación Cardiopulmonar; Tecnología Educacional; Educación a Distancia; Simulación; Estudios de Validación.

\section{REFERENCES}

1. Malta Hansen C, Rosenkranz SM, Folke F, Zinckernagel L, Tjørnhøj-Thomsen T, Torp-Pedersen C, et al. Lay bystanders' perspectives on what facilitates cardiopulmonary resuscitation and use of automated external defibrillators in real cardiac arrests. J Am Heart Assoc [Internet]. 2017 [cited 2017 May 2];6(3):e004572. Available from: https://www.ncbi.nlm.nih.gov/pmc/articles/PMC5524003/ 
2. American Heart Association. Guideline 2015 CPR \& ECC. Destaques das Diretrizes da American Heart Association 2015. Atualização das Diretrizes RCP e ACE [Internet]. Dallas, TX; 2015 [citado 2017 abr. 20]. Disponível em: http://eccguidelines.heart.org/wp-content/ uploads/2015/10/2015-AHA-Guidelines-Highlights-Portuguese.pdf

3. Mansur AP, Favarato D. Trends in mortality rate from cardiovascular disease in Brazil, 1980-2012. Arq Bras Cardiol [Internet]. 2016 [cited 2017 Apr 27];107(1):20-5. Available from: http://www.scielo.br/scielo.php?script=sci_arttext\&pid=S0066-782X2016005015101\&lng=en \&nrm=iso\&tlng=en

4. Meira Júnior LE, Souza FM, Almeida LC, Veloso GGV, Caldeira AP. Treinamento em SBV para médicos e enfermeiros da atenção primária. Rev Bras Med Fam Comun [Internet]. 2016 [citado 2017 abr. 27];11(38):1-10. Disponível em: https://rbmfc.org.br/rbmfc/article/view/1231

5. Galvão ECF, Puschel VAA. Multimedia application in mobile platform for teaching the measurement of central venous pressure. Rev Esc Enferm USP [Internet]. 2012 [cited 2017 Apr 25];46(7):107-15. Available from: http://www.scielo.br/scielo.php?pid=S0080$62342012000700016 \&$ script=sci_arttext\&tlng=en

6. Brasil. Ministério da Saúde. Portaria n. 198/GM/MS, de 13 de fevereiro de 2004. Institui a Política Nacional de Educação Permanente em Saúde como estratégia do Sistema Único de Saúde para a formação e o desenvolvimento de trabalhadores para o setor e dá outras providências [Internet]. Brasília; 2004 [citado 2017 abr. 27]. Disponível em: http://bvsms.saude.gov.br/bvs/saudelegis/gm/2017/ MatrizesConsolidacao/comum/13150.html

7. Salvador PTCO, Mariz CMS, Vítor AF, Ferreira Júnior MA, Fernandes MID, Martins JCA, et al. Validation of virtual learning object to support the teaching of nursing care systematization. Rev Bras Enferm [Internet]. 2018;71( 1 ):11-9. DOI: http://dx.doi.org/10.1590/0034-71672016-0537

8. Fotheringham D. Confident to seek help: the development of skill and judgement in nurse practitioners. Nurse Educ Today. 2013;33(7):7018. DOI: http://dx.doi.org/10.1016/j.nedt.2013.03.007

9. Lewis PA, Mai VA, Gray G. Bilingual asynchronous online discussion groups: design and delivery of an eLearning distance study module for nurse academics in a developing country. Nurse Educ Today. 2012;32(3):315-9. DOI: 10.1016/j.nedt.2011.02.011

10. Polit DF, Beck CT. The content validity index: are you sure you know what's being reported? Critique and recommendations. Res Nurs Health. 2006;29(5):489-97. DOI: 10.1002/nur.20147

11. Soares NA, Gazzinelli MF, Souza V, Araújo LHL. Role Playing Game (RPG) na graduação em enfermagem: potencialidades pedagógicas. Rev Eletr Enf [Internet]. 2016 [citado 2017 maio 8];18. Disponível em: https://www.revistas.ufg.br/fen/article/view/37672/21999

12. Pasquali L. Instrumentação psicológica: fundamentos e práticas. Porto Alegre: Artmed; 2010.

13. Fehring RJ. The Fehring model. In: Carrol-Johnson RM, Paquete M. Classification of nursing diagnoses: proceeding of the tenth conference. Philadelphia: Lippincott; 1994. p. 55-62.

14. Costa IKF, Medeiros LP, Dias TYAF, Salvetti MG, Dantas DV, Torres GV. Protocol validation for people with venous ulcers: a quantitative study. Online Braz J Nurs [Internet]. 2016 [cited 2017 Apr 13];15(2):226-35. Available from: http://www.objnursing.uff.br/index.php/ nursing/article/view/5251

15. Freitas CCS, Costa IKF, Costa IKF, Lira ALBC, Feijão AR, Torre GV. Educational technology in vocational training of emergency services. Int Aarch Med [Internet]. 2016 [cited 2017 Apr 28];9(190):1-9. Available from: http://imed.pub/ojs/index.php/iam/article/view/1642

16. Szögedi I, Zrínyi M, Bethehem J, Ujváriné AS, Tóth H. Training nurses for CPR: support for the problem-based approach. Eur J CardiovasC Nurs. 2010;9(1):50-6.

17. Ausubel DP. Aquisição e retenção de conhecimentos. Lisboa: Plátano Edições Técnicas; 2003.

18. Day-Black C, Merril EB, Konzelman L, Williams TT, Hart N. Gamification: an innovative teaching-learning strategy for the digital nursing students in a community health nursing course. ABNF J. 2015;26(4):90-4.

19. Perkins GD, Jacobs IG, Nadkarni VM, Berg RA, Bhanji F, Biarent D, et al. Cardiac arrest and cardiopulmonary resuscitation outcome reports: update of the Utstein Resuscitation Registry templates for out-of-hospital cardiac arrest. Circulation. 2015;132(13):1286-300. DOI: https:// doi.org/10.1161/CIR.0000000000000144

20. Lin Y, Ng K, Exadaktylos AK, Ryan JM, Wu H. Shock, cardiac arrest, and resuscitation. Biomed Res Int [Internet]. 2017 [cited 2017 Apr 18];2017:5743702. Available from: https://www.ncbi.nlm.nih.gov/pmc/articles/PMC5239832/

21. Hategeka C, Shoveller J, Tuyisenge L, Kenyon C, Cechetto DF, Lynd LD. Pediatric emergency care capacity in a low-resource setting: an assessment of district hospitals in Rwanda. PLoS One [Internet] 2017 [cited 2017 May 8];12(3):e0173233. Available from: https://www. ncbi.nlm.nih.gov/pmc/articles/PMC5336272/

22. Idris AH. The sweet spot: chest compressions between 100-120/minute optimize successful resuscitation from cardiac rest. JEMS [Internet]. 2012 [cited 2017 May 8];37(9):4-9. Available from: https://www.ncbi.nlm.nih.gov/pmc/articles/PMC5239832/

23. Hafner JW, Sturgell JL, Matlock DL, Bockewitz EG, Barker LT. "Stayin' alive": a novel mental metronome to maintain compression rates in simulated cardiac arrests. J Emerg Med. 2012;43(5):e373-7. DOI: 10.1016/j.jemermed.2012.01.026.

24. Tastan S, Ayhan H, Unver V, Cinar FI, Kose G, Basak T, et al. The effects of music on the cardiac resuscitation education of nursing students. Int Emerg Nurs. 2017;31:30-5. DOI: 10.1016/j.ienj.2016.06.007

25. Solomonidou C, Stavridou H. Design and development of a computer learning environment on the basis of students' initial conceptions and learning difficulties about chemical equilibrium. Educ Inf Technol. 2001;6(1):5-27.

26. Costa MPF, Miyadahira AMK. Desfibriladores externos automáticos (DEA) no atendimento pré-hospitalar e acesso público à desfibrilação: uma necessidade real. Mundo Saúde [Internet]. 2008 [citado 2017 maio 8];32(1):8-15. Disponível em: http://www.saocamilo-sp.br/pdf/ mundo_saude/58/08a15.pdf

27. Cook NF, McAloon T, O'Neill P, Beggs R. Impact of a web based interactive simulation game (PULSE) on nursing students' experience and performance in life support training--a pilot study. Nurse Educ Today. 2012;32(6):714-20. DOI: 10.1016/j.nedt.2011.09.013 